\title{
HYDRATION AND MICROSTRUCTURE OF IRRADIATED CONCRETES
}

\author{
放射線を照射されたコンクリートの水和特性と微細構造
}

\author{
Masayoshi KAKIZAKI*, Yoshio IDEI***, Takenori SUKEGAWA***, \\ Youichi AKUTSU*****, Hitoshi KURIOKA** \\ and Kiyotaka SUZUKI ${ }^{* * * * * *}$ \\ 柿崎正義, 出井義男, 助川武則, 圷陽一 \\ 栗岡均, 鈴木 清 孝
}

\begin{abstract}
This study aims to obtain basic knowledge of predicting the life of power reactors. To this end, biological shield concretes in Japan Power Demonstration Reactor (JPDR) exposed to radiations under long term operation was inspected in terms of hydration behavior and microstructure, and compared with model specimens cured under the same thermal conditions. Major findings are as follows,

a. SEM observation showed that needle-like crystals in concrete exhibited greater development at the reactor core side than at the perimeter, and they had similar shapes to ettringite and C-S-H as observed in the model specimens.

b. Bound water content of mortar was $5 \%$ larger at the reactor core side than at the perimeter, whereas it was average $6.5 \%$ larger in the model specimen. This tendency agrees well with the analysis of concrete in JPDR.

c. Hydration products assigned by X-ray diffraction for the model specimens were monosulfate and calcium hydroxide, which were coincide with the analysis of concrete in JPDR.

d. Pore size distribution of concrete showed larger amount of small pores at the reactor core side than at the perimeter. This tendency agrees well with the model specimens with a seal.

e. Hydration and microstructure analysis of the model specimens supported the test results that the biological shield concrete undergoes no substantial changes.

Keywords : Biological Shield Concrete, Neutron Fluence, Gamma-ray Dose, Hydration 生体遮蔽コンクリト 中性子照射落照射量＼cjkstart水和特性

Pore Size Distribution, Microstructures

細孔径分布微細構造
\end{abstract}

\section{Introduction}

Concrete structures is one of the key components which has a possibility to greatly affect the life of power reactors whereby it is necessary for life control to estimate, in a sufficient accuracy, changes of the concrete with time under operations. Studies of changes in properties of irradiated concretes, which is specific to power reactors, have been made with small specimens subjected to intensive radiations in a shot moment. The target reactor was the Japan Power Demonstration Reactor ( JPDR), the first small light water reactor that generated power of thermal $45 \mathrm{MW}$ (Modified for double 90 Mw : JPDR - II) in Japan, aged 26 years (18 years after operation was stopped) in 1986 [1]. Though the duration of actual operation was short, the irradiation dose of the biological shield concrete in the JPDR may correspond to that of 40 years operation of large power reactors now in use.

The irradiation dose of the biological shield concrete in the JPDR and the its effects on the mechanical properties were studied in our previous paper [3]. The maximum irradiation $(\mathrm{E}>0.11 \mathrm{MeV})$ was $1.1 \times 10^{18} \mathrm{n} / \mathrm{cm} 2$ and the maximum gamma ray irradiation was $4.8 \times 10^{8} \mathrm{~Gy}$. The compressive strength and modulus of elasticity of the specimen subjected to fast neutron irradiation $\left(1 \times 10^{13}-1.86 \times 10^{17} \mathrm{n} / \mathrm{cm}^{2}\right)$ were $29.53 \mathrm{MPa}$ and $2.1-4.7 \times 10^{4} \mathrm{MPa}$ respectively .

This study aims to obtain basic knowledge of predicting the life of power reactors. To this end, biological shield concretes specimens in JPDR exposed to neutron and gamma ray heat generation were tested in terms of hydration behavior and microstructure and compared with model specimens under the same thermal conditions as JPDR[3].

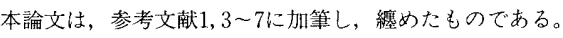

* Projects Manager, Kajima Technical Research Institute, Dr. Eng.

** Chief Research Eng., Kajima Technical Research Institute

*** Prime Chief, JAERI, Tokai Research Establishment, Dept. of Reactor Safety Research

**** Chief, JAERI, Dept. of Decommissioning and Waste Management

***** General Manager, JAERI, Dept. of Construction

****** General Manager, Kajima Corporation, Construction Group, Nagoya Branch
}

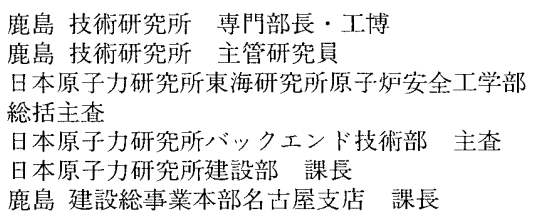




\section{Outline of the biological shield concretes}

The biological shield concrete in JPDR was a reinforced concrete with a steel liner of $13 \mathrm{~mm}$ thick at reactor core side, a relay liner in the midpoint and epoxy coatings on the exterior surfaces. On the surface of the reactor core side, seven neutron monitor guide tubes and cooling pipes were settled to reduce temperature rise due to gamma ray radiation [1].

Design conditions for biological shield concretes are as follows [1, 2],

a. Thickness of concrete : 150 to $300 \mathrm{~cm}$, b. Slump : $7.5 \mathrm{~cm}$

c. Mixture design : Designed strength : $35 \mathrm{MPa}$,

d. Type of concrete : Normal weight concrete

e. Mixture proportions : See Table 1

The other conditions such as reinforcement constructions, specifications for steel bars including tensile strength and strain, placement conditions for concrete, irradiation period (operation period) are shown in the chapter 2 of the reference No. 3.

\section{Experiment}

\subsection{Items of tests}

Methods and items of tests for hydration and microstructure of biological shield concretes (Experiment 1) [1] and model specimens (Experiment 2) are listed in Table 2.

\subsection{Specimen preparations}

(1) Biological shield concrete (Experiment 1)

The same core samples as used in the previous study [3] of irradiation dosage and mechanical properties of the biological shield concrete were subjected to analysis of hydration characteristics and microstructure. Thickness of the cores was all the same to have an equal effect of the degree of irradiation, but the distance from the reactor core was varied to see the difference in hydration characteristics and microstructure according to the degree of irradiation [3]. Sampling points (directions) and the height were the same as the previous study [3] and are shown in Fig.1, and cutting points and names of sampled cores for analysis are shown in Fig. 2 and sampling procedures of specimens subjected to analysis are shown in Fig. 3. The concrete cores, sampled according as JS A 1107 , were prepared according to the need of the test described in 3.3 (1) and (2) [5, 6].

(2) Model specimen under thermal effects ( Experiment 2 )

Model specimens were prepared with a mixture proportion (Table 1) as close as possible to that of the biological shield concretes in JPDR and shaped in $150 \mathrm{~mm}$ in diameter and $300 \mathrm{~mm}$ in height according to JS A 1132 ҐMethod of preparing a specimen for strength tests $\rfloor$. Since the biological shield concrete has a steel liner of $13 \mathrm{~mm}$ thick in the interior surface, considerable moisture may have remained in concrete throughout the operation. To simulate this condition, concrete of the model specimens were placed into a thin copper tube with $0.3 \mathrm{~mm}$ in thickness, $150 \mathrm{~mm}$ in diameter and $300 \mathrm{~mm}$ in height, which was previously set in a steel mold. The concrete was placed in three evenly divided volumes, compacted by a vibrator, trowelled after bleeding and sealed with a copper plate. Unsealed specimens were prepared in the same fashion as the sealed specimen except for placing directly into a steel mold. Standard cured specimens were demolded after being kept in the steel mold for two days under a room temperature of $20^{\circ} \mathrm{c}$ and subjected to the standard curing, while steam cured specimens were demolded after a natural cooling from the preliminary curing of 10 hours after placing and subjected to the secondary curing.

3.3 Test method [5, 6]

(1) Biological shield concrete
Table 1 Mixture Proportions of Concrete

\begin{tabular}{|c|c|c|c|c|c|c|}
\hline \multirow{2}{*}{$\begin{array}{c}\text { WATER } \\
\text { CEMENT } \\
\text { RATIO }\end{array}$} & \multirow{2}{*}{$\begin{array}{c}\text { SLUMP } \\
(\mathrm{cm})\end{array}$} & \multirow{2}{*}{$\begin{array}{c}\text { UNIT } \\
\text { WATER } \\
\left(\mathrm{kg} / \mathrm{m}^{3}\right) \\
\end{array}$} & \multicolumn{3}{|c|}{$\begin{array}{l}\text { UNIT AMOUNT } \\
\left(\mathrm{kg} / \mathrm{m}^{3}\right)\end{array}$} & \multirow{2}{*}{\begin{tabular}{|c}
$\begin{array}{c}\text { ADMIXTURES } \\
\text { (Mass } \% \text { of Cement) }\end{array}$ \\
AWR \\
\end{tabular}} \\
\hline & & & Cement & FA & $\mathrm{CA}$ & \\
\hline 0.47 & 7.5 & 139 & 290 & 653 & 1240 & 0.3 \\
\hline
\end{tabular}

Table 2 Methods and Items of Test

\begin{tabular}{|c|c|c|c|}
\hline \multirow{2}{*}{ METHODS } & \multirow{2}{*}{ TEST ITEMS } & \multicolumn{2}{|c|}{ SPECIMENS } \\
\hline & & JPDR* & MODEL** \\
\hline $\begin{array}{l}\text { MORPHOLOGY } \\
\text { OF HYDRATION } \\
\text { PRODUCTS }\end{array}$ & $\begin{array}{c}\text { SEM } \\
\text { OBSERVATION }\end{array}$ & 0 & 0 \\
\hline $\begin{array}{c}\text { X-RAY } \\
\text { DIFFRACTION }\end{array}$ & $\begin{array}{l}\text { IDENTIFICATION } \\
\text { OF CRYSTALLINE } \\
\text { HYDRATES }\end{array}$ & 0 & $\mathrm{O}$ \\
\hline $\begin{array}{l}\text { BOUND WATER } \\
\text { CONTENT }\end{array}$ & $\begin{array}{l}\text { STATE OF WATER } \\
\text { IN CONCRETES }\end{array}$ & 0 & 0 \\
\hline $\begin{array}{l}\text { THERMAL } \\
\text { ANALYSIS }\end{array}$ & DTA AND TG-DTA & 0 & 0 \\
\hline $\begin{array}{c}\text { PORE } \\
\text { STRUCTURE }\end{array}$ & $\begin{array}{l}\text { CHANGES IN PORE } \\
\text { DISTRIBUTIONS }\end{array}$ & 0 & 0 \\
\hline
\end{tabular}

Notes * Hydration and microstructure of concrete for JPDR

** Hydration and microstructure of model concrete imagined influence of thermal

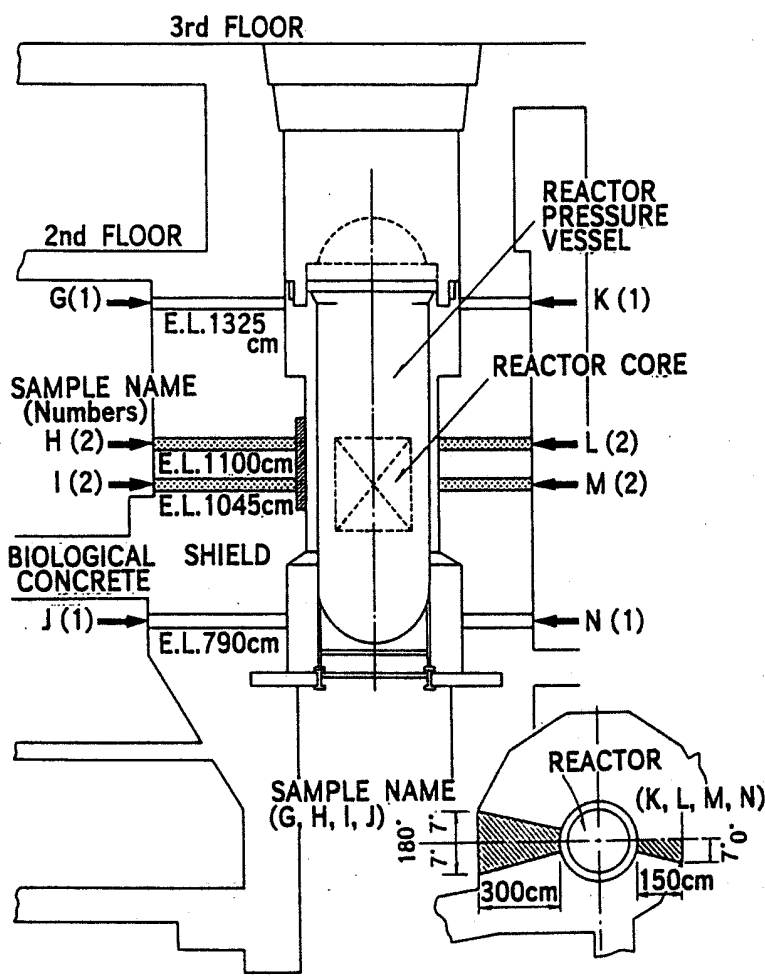

Fig. 1 Sampling Points (Directions) and the Height of Reactor Containment of JPDR 


\section{1) SEM observations}

A mortar part (3- 5 cubic millimeter, dry condition ) taken from a rougly ground concrete sample was dried in vacuum, subsequently split to have a fracture plane on which gold was deposited. Observation was made in a magnification of 500, 1000, 3000 and 10000 times at each two fields of view for a sample.

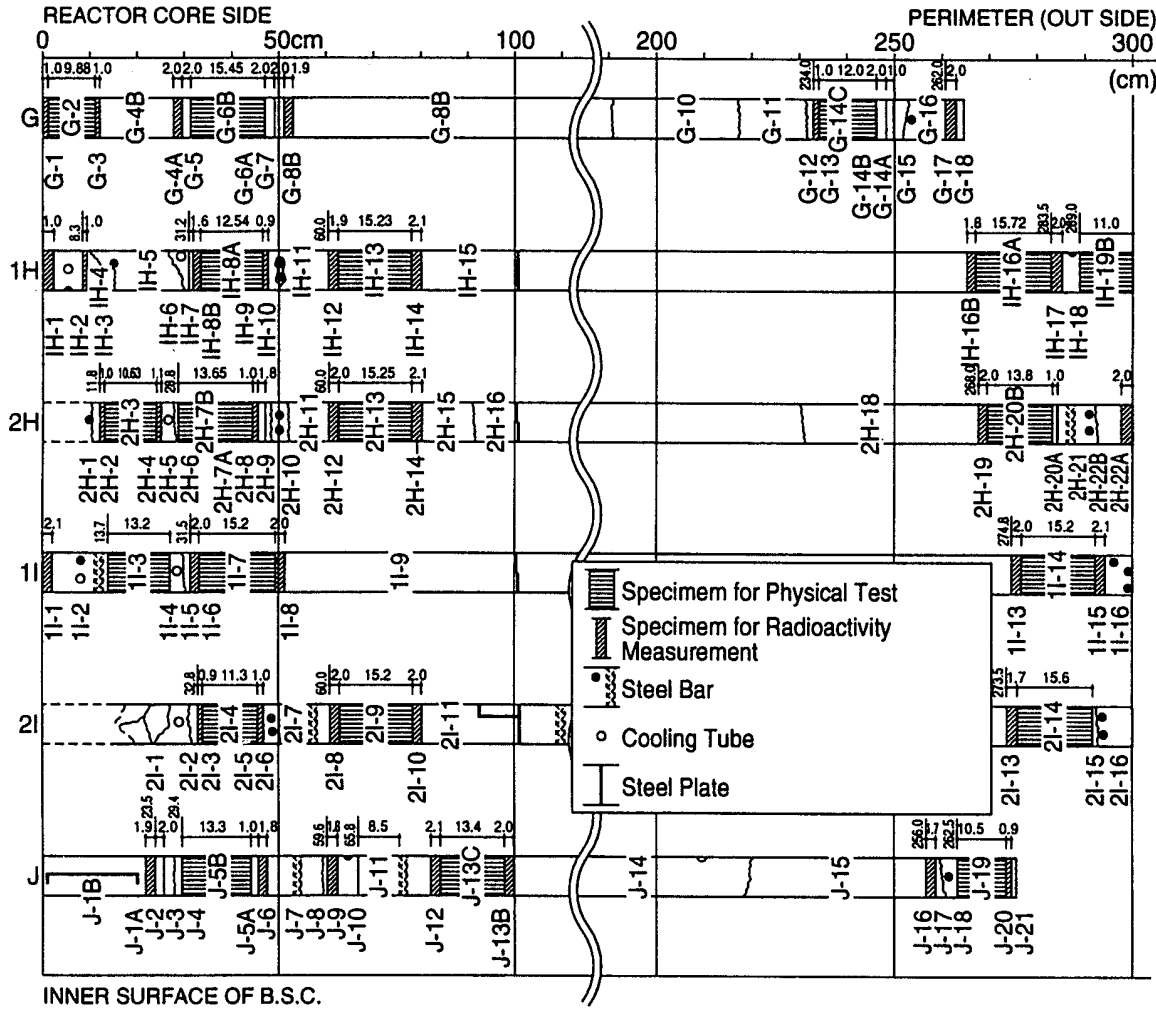

Fig. 2 Cutting Points and Names of Sampled Cores for Analysis

2) X-ray diffraction

About one grams of powder for gamma-ray diffraction analysis was taken from a mortar part (dry condition) finely ground less than $45 \mathrm{mi}$ crometers, placed on a glass plate and subjected to analysis. Diffraction angles (20) were measured and the spacings of lattice planes were calculated from the Bragg's equation and the crystalline phases were assigned with reference to the JCPDS card [ 5,6 ]. (indoor temperature : $20-25^{\circ} \mathrm{C}$ ).

3) Bound water content and differential thermal analysis

A five grams of powder was taken from a mortar part finely ground less than 45 micrometers and dried at $40^{\circ} \mathrm{C}$ for 24 hours, and moisture content and bound water content were calculated using following formulas with weight loss data at temperatures of $105,400,650$ and $950^{\circ} \mathrm{C}$ in an electric furnace. From the entire DTA curve, weight loss between $600^{\circ} \mathrm{C}$ to $700^{\circ} \mathrm{C}$ that corresponds to the decomposition of carbonates was negligible thereby $650^{\circ} \mathrm{C}$ was used as the upper limit temperature for the bound water estimation .

Moisture content $=$ (weight before drying - weight after drying) $\times 100 /$ (weight before drying) $(\%)$,

Bound water content $=\left(\right.$ Moisture content at $\left.650^{\circ} \mathrm{C}\right)-\left(\right.$ Moisture content at $\left.105^{\circ} \mathrm{C}\right)$.

A 10 milli- grams of powder was taken from a mortar part finely ground less than $\mathbf{4 5}$ micrometers and was heated at a heating rate of $10 \mathrm{deg} / \mathrm{min}$ up to $950^{\circ} \mathrm{C}$ by a differential thermal analyzer using an alpha $(\alpha)$ - alumina as a reference material. Calcium hydroxide content was calculated using the following formula.

Calcium hydroxide content $=\left(\right.$ moisture content at $\left.440-500^{\circ} \mathrm{C}\right) / 0.246(\%)$,

where a coefficient of 0.246 is a water content of calcium hydroxide.

Area under the endothermic peak of $\mathrm{Ca}(\mathrm{OH}) 2$ dehydration was determined by block counting method in the grid paper where the chart output from the X-Y recorder was transferred.

4) Pore size distribution

A 30 grams of mortar part was taken from the concrete sample, subjected to ultrasonic cleaning in an ethanol solution and dried at $105^{\circ} \mathrm{C}$ for 30 minutes. Mercury porosimetry was operated at a pressure range of 0.09 to $200 \mathrm{MPa}$ which 
corresponds to a pore size from 6 to $9500 \mathrm{~nm}$. The mean pore radius was calculated using the following formula.[5, 6]

Mean pore radius $=$ total pore volume $/($ specific surface area $) \times 2$

(2) Model specimen taking account of thermal effects

1) Curing conditions

Curing conditions of the model specimens taking account of thermal effects are shown in Fig. 4. To simulate a concrete subjected to a long term heat exposure due to irradiation from the reactor, two types of curing were applied; a primary steam curing corresponding to a hydration heat followed by a curing at $20^{\circ} \mathrm{C} \mathrm{(No.1} \mathrm{method),} \mathrm{or} \mathrm{at} 50^{\circ} \mathrm{C} \mathrm{(} \mathrm{No.2}$ method) that presume a concrete closer to the reactor core. Each two curing conditions has two cases with or without a seal of copper tube imitating a concrete near the liner or midpoint of massive concrete where moisture content is likely to be high and the other concrete whose surface is not closed or thickness is not so large. For control specimens, the No.3 curing method presuming a midpoint of concrete with less moisture variations and the No.4 curing method presuming a location far from the reactor core with a temperature as low as $20^{\circ} \mathrm{C}$, are adopted.

The primary steam curing, presuming an effect of hydration heat in real structures, was executed at a heating rate of $5^{\circ} \mathrm{C} / \mathrm{h}$ to a maximum temperature of $60^{\circ} \mathrm{C}$ and kept for 24 hours, while the secondary steam curing, presuming a heat due to gamma ray radiations [3] in real structures, was executed under a temperature of 50 or $20^{\circ} \mathrm{C}$ and a relative humidity of $60 \%$. Control specimens were cured under a temperature of $20^{\circ} \mathrm{C}$ and a relative humidity of $60 \%$ or cured in water bath at a temperature of $20^{\circ} \mathrm{C}$. Temperature history at curing was measured by a thermocouple embedded in dummy specimens.

\section{2) Hydration and microstructure}

Hydration behavior and microstructure of the model specimens were analyzed [Note 1] by the same methods; SEM observation, X-ray diffraction, bound water content and thermal analysis, as described in 3.3 (1) with specimens of finely powdered cement mortar obtained by subtracting aggregates from concrete as shown in Fig. 3. Bound water content, thermal analysis and pore size distribution were measured by the same fashion as described in 3.3 (1). The SEM observation of the hydration products was a visual inspection just to confirm the existence in a qualitative manner.

\section{Temperature distribution analysis and discussions}

Temperature histories of the biological shield concrete in JPDR comprise hydration heat and heating due to irradiation during operation. Methods and results of the analysis were given in the section 3.3 of the reference [3], and can be summarized as follows.

4.1 Temperature distribution due to hydration heat

The maximum temperature due to hydration heat was estimated to be $58^{\circ} \mathrm{C}$ in the midpoint of the biological shield concrete, while the temperature difference between the midpoint and the edges was 32 degree.

\subsection{Temperature distribution due to irradiation under operations}

The maximum temperature due to irradiation under a normal operation was estimated to be $46^{\circ} \mathrm{C}$ at the surface of the biological shield concrete of the reactor core side, $36^{\circ} \mathrm{C}$ in the interface between the liner and the concrete and $25^{\circ} \mathrm{C}$ in the vicinity of cooling pipes. The maximum temperature difference worked out to be 20 degree implying an effectiveness of cooling pipes that embedded in the biological shield concrete.

\section{Results and discussions}

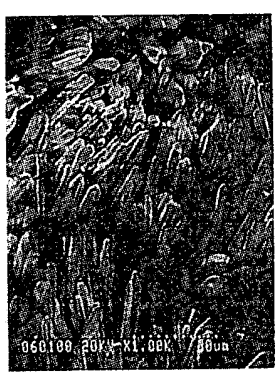

Sample :11-3

Location : Reactor core side

Fig. 5 Typical Examples of Scanning Electron Micrograph

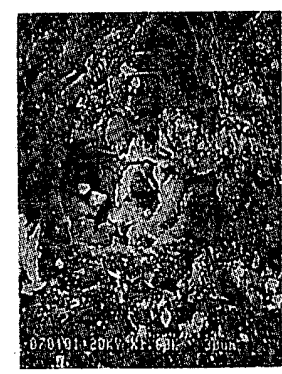

Sample :11-14 Location : Reactor outside

Fig. $6 \mathrm{X}$-ray Diffraction Pattern
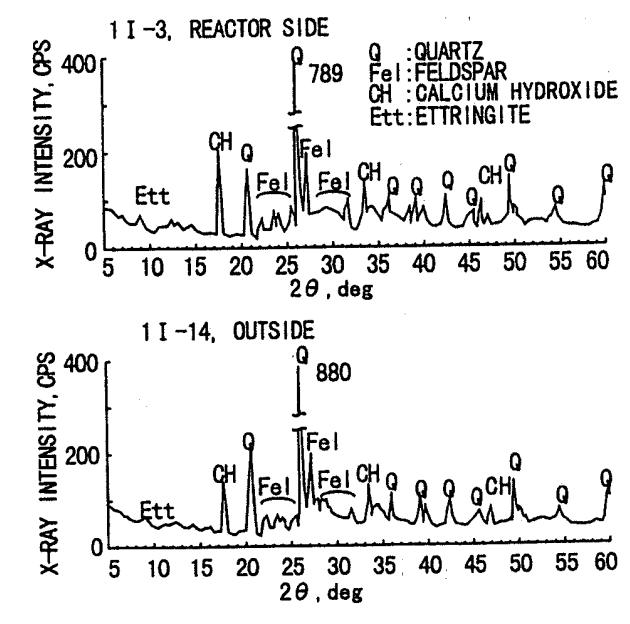

5.1 Hydration and microstructure of biological shield concrete

(1) SEM observations

Typical examples of scanning electron micrograph viewing a mortar part of concretes taken from the reactor core side and from the perimeter (1I- core) are shown in Fig. 5. A larger amount of needle-like crystals were observed in larger pores, where crystalline phase of hydrates are likely to grow, of the samples from the reactor side than that from the perimeter, while small amount of mesh-like crystals could be seen only in the sample from the perimeter. This tendency was also conspicuous in samples of $1 \mathrm{H}$, $2 \mathrm{H}$ and $1 \mathrm{I}$ - core. Growth of the mesh-like crystals may be attributed to the temperature rise due to radiations and to moisture conditions due to the presence of the liner, whereas the growth showed differences according to the height of the sampling point.

(2) X-ray diffraction of hydration products

An example of X-ray diffraction pattern of the mortar part of concretes taken from the reactor core side and from the perimeter (1I-core) are shown in Fig. 6. Crystalline phases assigned were calcium hydroxide : $\mathrm{Ca}(\mathrm{OH})_{2}$ $2 \theta-18.1^{\circ}$, ettringite : $\mathrm{SCaO}-\mathrm{Al}_{2} \mathrm{O}_{3}-3 \mathrm{CaSO}_{4}-32 \mathrm{H}_{2} \mathrm{O}, 2 \theta-9.1^{\circ}$, quartz and feldspar. Amount of calcium hydroxide was slightly larger at the reactor core 
side than at the perimeter and that of ettringite was much larger at the reactor core side.

(3) Amount of bound water and thermal analysis of hydration products

Heating weight loss and amount of bound water of mortar part of the specimens is shown in Table 3. Amount of evaporable water of specimens taken from the reactor core side was $12 \%$ larger than that from the perimeter and amount of the other type of water was less than $5 \%$ in average and slightly larger than that of the perimeter. Bound water content of specimens taken from the reactor core side was $6.89 \%$ while that from the perimeter was $6.58 \%$. An example of DTA chart is shown in Fig. 7. An endothermic peak due to a dehydration of calcium hydroxide can be seen at 0.75 to 1.3 times (Table 4 ) with respect to that from the perimeter. This implies that the amount of $\mathrm{Ca}(\mathrm{OH}) 2$ in the reactor core side is less than that

Table 3 Heating Weight Loss and Amount of Bound Water (BW) of Mortar

\begin{tabular}{|c|c|c|c|c|}
\hline & \multicolumn{2}{|c|}{ (Unit : wt\%) } \\
\hline $\begin{array}{ll}\text { HEATING } \\
\text { SAMPLING }\end{array}$ & $105^{\circ} \mathrm{C}$ & $400^{\circ} \mathrm{C}$ & $650^{\circ} \mathrm{C}$ & BW * \\
\hline LOCATIONS & $1 \mathrm{hr}$ & $1 \mathrm{hr}$ & $1 \mathrm{hr}$ & $1 \mathrm{hr}$ \\
\hline REACTOR CORE SIDE & 1.86 & 4.27 & 2.62 & 8.32 \\
\hline OUTSIDE & 1.66 & 4.09 & 2.49 & 8.01 \\
\hline REACTOR SIDE/OUTSIDE & 1.12 & 1.04 & 1.05 & 1.05 \\
\hline $\begin{array}{r}\text { Notes, Reactor core side } \\
\text { Outside : Average } \\
\text { * Amount of bound w }\end{array}$ & $\begin{array}{l}\text { Averag } \\
1 \mathrm{H}-16 \\
\text { ar }\end{array}$ & $1 \mathrm{H}-8 \mathrm{~A}$ & $\begin{array}{l}4-3,11- \\
4,21-1\end{array}$ & \\
\hline
\end{tabular}

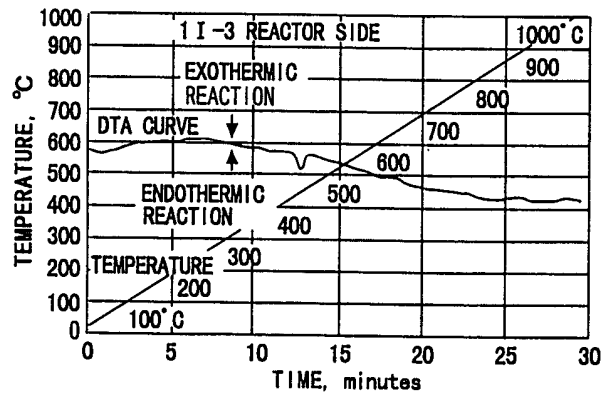

Fig. 7 An Example of DTA Chart of Mortar in the perimeter

(4) Pore size distribution and pore volume

Pore size distribution and total pore volume of specimens taken from the reactor core side and from the perimeter are shown in Fig. 8 and Table 5 . The differential pore volume exhibited a peak at a pore size range from 13 to $45 \mathrm{~nm}$, which was common to all specimens, while a total picture of pore size distribution of samples taken from the reactor core side was shifted to the smaller side compared to that from the perimeter. Total pore volume of samples taken from the reactor core side, samples I and $\mathrm{H}$ for example, was $49.7 \mathrm{~mm}^{3} / \mathrm{g}$ which was $13 \%$ smaller than that from the perimeter implying a slight densification of the matrix.

\subsection{Hydration and microstructure of the model specimen}

(1) SEM observations

Results of SEM observations according to curing conditions No.1, 2, 3 and 4 are listed in Table 6. In specimens cured in No. 2 condition presuming a location near the reactor core, monosulfate (a plate-shaped crystal about 1 micrometers in dimension), calcium hydroxide ( a layered, plate-shaped crystal about few micrometers in dimension) and hydrogarnet (a small spherical crystal about 0.3 micrometers in dimension) were observed regardless of the presence of seal, while ettringite ( a needle-like crystal about 1 micrometers in dimension) and C-S-H ( a granulated or mesh-like particle less than 1 micrometers in dimension) were predominantly observed in samples without a seal than those with a seal. In specimens cured in No. 4 condition presuming a location far from the reactor core, ettringite, calcium hydroxide and C-S-H were observed while monosulfate and hydrogarnet were not observed, and amount and dimensions of calcium hydroxide and C-S-H increased with the lapse of time. Type of hydration products differed according to a temperature history at early ages (a curing condition of No.1 without a seal and No. 4), while as a whole, no significant difference was observed according to the long term temperature history or to the presence of a seal.

(2) X-ray diffraction of hydration products

Examples of X-ray diffraction pattern of specimens cured by No.2 method and changes in hydration products are
Table 4 Compared by Area under the Peak of Calcium Hydroxide

\begin{tabular}{|c|c|c|c|c|c|}
\hline $\begin{array}{c}\text { CORE } \\
\text { SAMPLING NAMES } \\
\text { LOCATIONS }\end{array}$ & $1 \mathrm{H}$ & $2 \mathrm{H}$ & 11 & 21 & AVERAGE \\
\hline $\begin{array}{c}\text { REACTOR } \\
\text { CORE SIDE }\end{array}$ & $\begin{array}{c}(1 \mathrm{H}-8 \mathrm{~A}) \\
1.30\end{array}$ & $\begin{array}{c}(2 \mathrm{H}-3) \\
0.75\end{array}$ & $\begin{array}{c}(11-3) \\
0.85\end{array}$ & $\begin{array}{c}(21-4) \\
1.14\end{array}$ & 1.07 \\
\hline OUTSIDE & $\begin{array}{c}(1 \mathrm{H}-16 \mathrm{~A}) \\
1\end{array}$ & $\begin{array}{c}(2 \mathrm{H}-20 \mathrm{~B}) \\
1\end{array}$ & $\begin{array}{c}(11-14) \\
1\end{array}$ & $\begin{array}{c}(21-14) \\
1\end{array}$ & 1 \\
\hline
\end{tabular}

Outside : Average of $1 \mathrm{H}-16 \mathrm{~A}, 2 \mathrm{H}-20 \mathrm{~B}, 11-14,21-14$

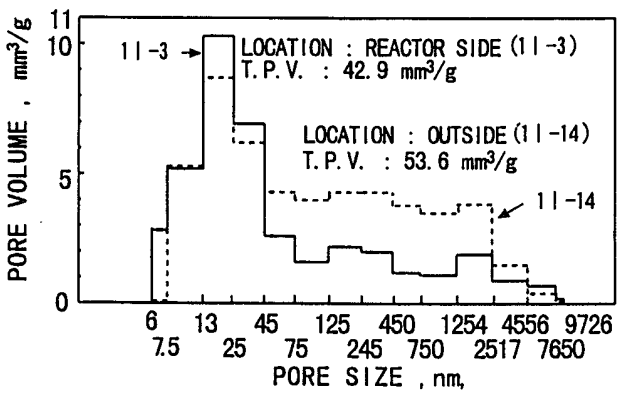

Fig. 8 Pore Size Distribution and Total Pore Volume of Mortar

Table 5 Compaction of Total Pore Volume

\begin{tabular}{|l|c|c|c|c|c|}
\hline $\begin{array}{r}\text { CORE } \\
\text { SAMPLING NAMES } \\
\text { LOCATIONS }\end{array}$ & $\mathrm{G}$ & $1 \mathrm{H}$ & $2 \mathrm{H}$ & 21 & $\mathrm{~J}$ \\
\hline $\begin{array}{c}\text { REACTOR } \\
\text { CORE SIDE }\end{array}$ & $(\mathrm{G}-2)$ & $(1 \mathrm{H}-8 \mathrm{~A})$ & $(11-3)$ & $(21-4)$ & $(\mathrm{J}-5 \mathrm{~B})$ \\
\hline & 66.30 & 39.90 & 42.90 & 49.80 & 56.6 \\
\hline OUTSIDE & - & $\begin{array}{c}(1 \mathrm{H}-16 \mathrm{~A}) \\
(2 \mathrm{H}-20 \mathrm{~B})\end{array}$ & $\begin{array}{c}(21-14) \\
56.5\end{array}$ & 51.7 & - \\
\hline
\end{tabular}

Outside : Average of $1 \mathrm{H}-16 \mathrm{~A}, 2 \mathrm{H}-20 \mathrm{~B}, 11-14,21-14$

Table 6 Observations of Hydrates (SEM)

\begin{tabular}{|c|c|c|c|c|c|c|c|}
\hline \multirow{2}{*}{$\begin{array}{l}\text { CURING } \\
\text { CONDI - } \\
\text { TIONS } \\
\text { No. }\end{array}$} & \multirow{2}{*}{$\begin{array}{l}\text { EXIST- } \\
\text { ENCE OF } \\
\text { SEAL }\end{array}$} & \multirow{2}{*}{$\begin{array}{c}\text { AGES } \\
\text { (Months) }\end{array}$} & \multicolumn{5}{|c|}{ HYDRATES ${ }^{* 1}$} \\
\hline & & & $\mathrm{ETT}^{* 4}$ & MONO & $\mathrm{CAL}^{* 6}$ & $\mathrm{C}-\mathrm{S}-\mathrm{H}$ & $\mathrm{HYD}^{* 7}$ \\
\hline \multirow{6}{*}{1} & \multirow{3}{*}{$\mathrm{sc}^{* 2}$} & $\begin{array}{c}\text { AFTER } \\
\text { PRIMARY } \\
\text { CURING }\end{array}$ & 0 & (ㅇ) & 0 & (ㅇ & (ㅇ) \\
\hline & & $1 \mathrm{MONTH}$ & 0 & (2) & (2) & (2) & (2) \\
\hline & & 3 MONTHS & 0 & (2) & (2) & 0 & (2) \\
\hline & \multirow{3}{*}{$A C^{* 3}$} & $\begin{array}{c}\text { AFTER } \\
\text { PRIMARY } \\
\text { CURING }\end{array}$ & (ㅇ) & (ㅇ) & 0 & (ㅇ) & (ㅇ) \\
\hline & & 1 MONTH & (2) & (2) & (2) & (2) & (2) \\
\hline & & 3 MONTHS & (2) & (2) & 0 & (2) & (2) \\
\hline \multirow{4}{*}{2} & \multirow{2}{*}{ sc } & 1 MONTH & 0 & (2) & (2) & 0 & (2) \\
\hline & & 3 MONTHS & 0 & (2) & (2) & 0 & (2) \\
\hline & \multirow{2}{*}{$A C$} & 1 MONTH & 0 & (2) & (2) & (2) & (2) \\
\hline & & 3 MONTHS & (2) & (2) & (2) & (2) & (2) \\
\hline 3 & $A C$ & 1 MONTH & (2) & $x$ & (2) & (2) & $x$ \\
\hline \multirow{2}{*}{4} & \multirow{2}{*}{ AC } & $1 \mathrm{MONTH}$ & (2) & $x$ & (2) & (2) & $x$ \\
\hline & & 3 MONTHS & () & $x$ & (9) & 0 & $x$ \\
\hline \multicolumn{8}{|c|}{ Notes: $* 1$ Mark: Amount of hydrates } \\
\hline \multicolumn{8}{|c|}{ (): Significant, 0 : Present, $\times$ : Absent } \\
\hline & \multicolumn{2}{|c|}{ *2 SC : Sealed Cured } & \multicolumn{5}{|c|}{ *5 MONO : MONOSULFATE } \\
\hline & \multicolumn{2}{|c|}{ *3 AC : Air Cured } & \multicolumn{5}{|c|}{ *6 CAL : CALCIUM HYDROXIDE } \\
\hline & *4 ETT: & TTRINGITTE & *7 HYD : & :HYDROC & ARNET & & \\
\hline
\end{tabular}


shown in Fig. 9 and 10 respectively. Crystalline phases of the hydrates assigned were unhydrated cement clinkers, calcium hydroxide, ettringite and monosulfate as well as quartz and feldspar originated from aggregates. A dehydrate gypsum was assigned in a specimen after the primary curing. Among the hydration reactions of cement at early stages, a $\mathrm{C}_{3} \mathrm{~A}$ reacts with a dehydrate gypsum to form an ettringite, however with a shortage of the gypsum, the ettringite may
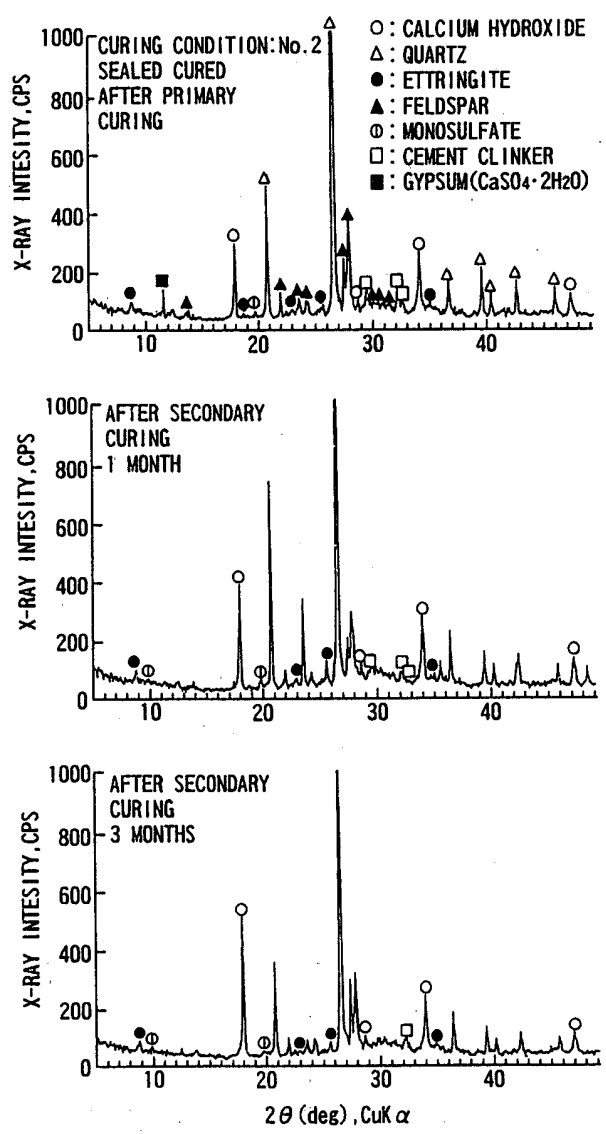

Fig. 9 X-ray Diffraction Pattern

transfer to a monosulfate in the presence of excessive $\mathrm{C}_{3} \mathrm{~A}$. Subsequent reactions involve hydration of $\mathrm{C}_{3} \mathrm{~S}$ and $\mathrm{C}_{2} \mathrm{~S}$, the main components in cement clinker, which results in a formation of $\mathrm{C}-\mathrm{S}-\mathrm{H}$ gels and calcium hydroxide. This reaction was traced by focussing on peaks at $32.1^{\circ}$, the most intensive peak for $\mathrm{C}_{2} \mathrm{~S}$ and $\mathrm{C}_{3} \mathrm{~S}$, and $18^{\circ}$, the most intensive peak for calcium hydroxide, while C-S-H was not detected by X-ray diffraction due to its poor crystalinity.

In specimens cured by No.2 method presuming a location near the reactor core, intensive peaks associated with ettringite, monosulfate and calcium hydroxide were detected showing agreement with the results of the biological shield concrete in JPDR. Evolution of hydration was developed in specimens without a seal more rapidly than those with a seal and accelerated by the ambient temperatures. Specimens cured in a high temperature at early ages showed a slow or retarded hydration subsequently.

\section{(3) Amount of bound water}

Amount of bound water during the hydration is shown in Fig. 11 and 12. The bound water increased with an increase in age regardless of the curing method. Amount of bound water of mortar cured with No.2 method presuming a location near the reactor core was $3.5-10 \%$ (average $6.5 \%$ ) larger than that cured by No.4 method presuming a location in the perimeter at ages of 1 and 3 months as shown in Fig. 11. However as shown in Fig. 12, amount of bound water of mortar cured with No. 2 method was about $12 \%$ larger than that of No. 4 cured until the ages of 3 months. Bound water of specimens cured (at ages of 1 and 3 months ) with No.2 method with a seal was 5 to $15 \%$ larger than that without a seal. This tendency agrees well with the analysis of concrete in JPDR. Model specimens with a seal generally had larger amount of bound water, probably

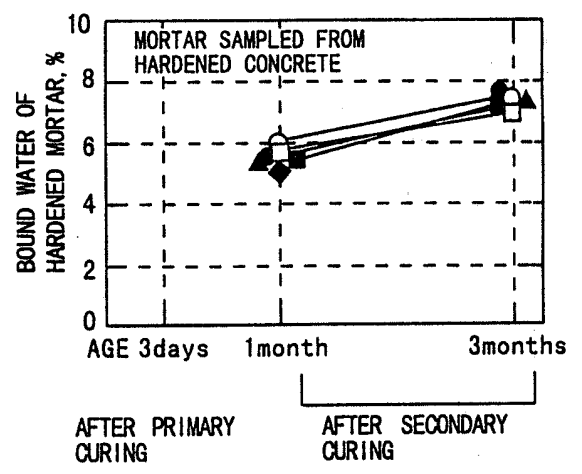

Fig. 11 Amount of Bound Water during the Hydration Determined by the Heating Weight Loss

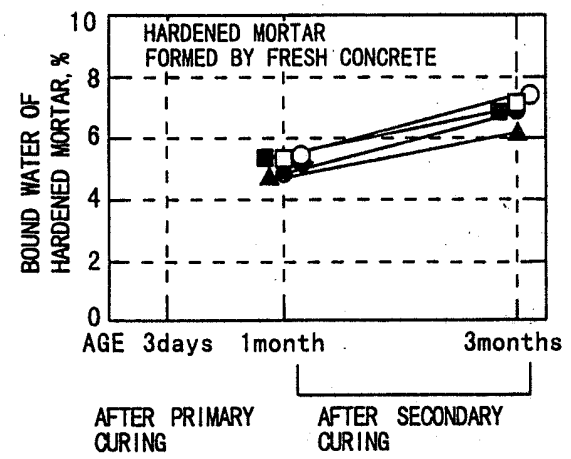

Fig. 12 Amount of Bound Water during the Hydration Determined by the Heating Weight Loss

\begin{tabular}{|c|c|}
\hline $\begin{array}{l}\text { Intensity of } \\
\text { Endothermic Peak } \\
\text { S: Strong } \\
\text { W: Middle } \\
\text { W: Heak } \\
\text { B : Broad }\end{array}$ & $\begin{array}{l}\text { Dehydration Temperature (DTA) } \\
\text { (1)Adhesion Hater } \\
\text { (2)-S-H(First) } \\
\text { (3)Ettringite(First) } \\
\text { (4) Gypsum } \\
\text { (5)Ettringite(Second) } \\
\text { (6) Honosulfate } \\
\text { (OHydrogarnet }\end{array}$ \\
\hline
\end{tabular}

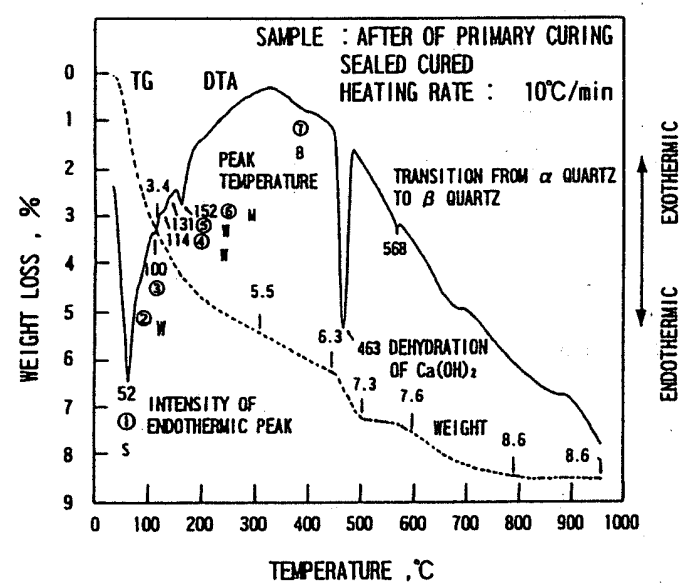

Fig. 13 Example of TG-DTA 
because the dimension of the sample was small enough to be dried more quickly. Probably by the same reason, bound water content of air cured hardened concrete was $5.5 \%$ larger than that cured in water (No. 3 method) but $10 \%$ less than that of shaped mortar. Bound water content increased with ages when specimens were subjected to heating at early ages and no difference was observed among the specimens. Bound water content of specimens subjected to a long term high temperature also increased with ages and the evolution of hydration was accelerated.

Table 7 Differential Thermal-Gravimetric Analysis (Endothemic peaks )

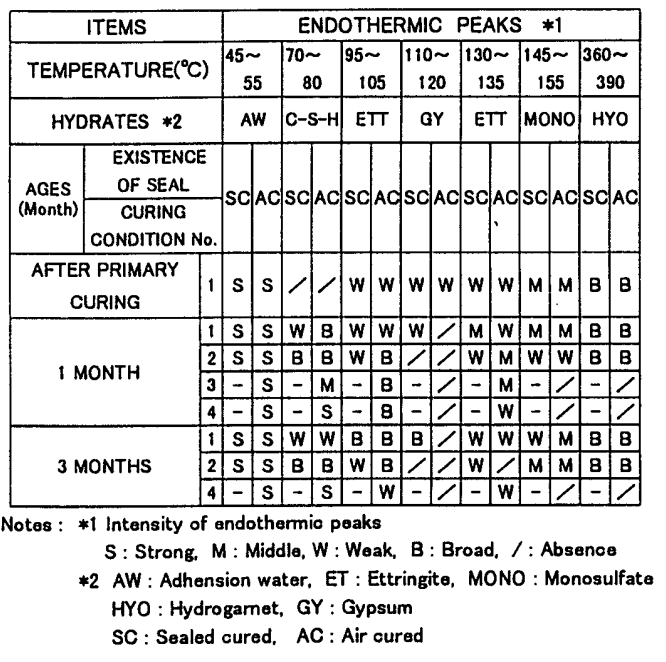

\section{(4) Thermal analysis (TG-DTA)}

An example of thermal analysis is shown in Fig. 13. Hydration products of cement were dehydrated at a range of high temperature, thereby amount of hydration products can be determined from endothermic peaks in the differential thermal - gravimetric analysis. Results are shown in Table 7. Amount of C-S-H in specimens cured with No. 3 and No. 4 method was larger than that cured with No. 1 or No. 2 , while amount of ettringite was not so different with each other. Hydrogarnet was detected at a broad peak near $370{ }^{\circ} \mathrm{C}$ for all ages of specimens cured with No. 1 and No. 2 method, but not for specimens cured with No.3 and No. 4 method corresponding to the result of SEM observation. An endothermic peak of calcium hydroxide in specimens cured with No. 2 method, presuming a location near the reactor core, was 12 to $17 \%$ larger than those cured with No. 4 method, presuming a location far from the reactor core, and an endothermic peak of calcium hydroxide in specimens with a seal was $17 \%$ smaller than those without a seal. Results of bound water content by thermal analysis is shown in Fig. 14, which exhibits a similar tendency to that determined by the heating weight loss (Fig. 11). Evolution of hydration of specimens without a seal became faster than that with a seal when a long term heating is applied.

(5) Pore size distribution and pore volume

A pore size distribution of specimen cured with No.2 method presuming a location near the reactor core is shown in Fig. 15. Differential pore volume of the mortar near the reactor core with a liner showed maximum at a pore size range from 7.5 to $45 \mathrm{~nm}$, while that located far from the reactor core (No.4 curing method) distributed over 7.5 to $7500 \mathrm{~nm}$. This tendency agrees well with the analysis of concrete in JPDR. Total pore volume, mean pore radius and age of specimens cured with No.1, 2, 3 and 4 are shown in Fig. 16. Total pore volume and mean pore radius of specimens cured with No.1 and No. 2 method and with a seal decreased slightly with ages implying the gradual densification of the matrix. When a heating applied at early ages, total pore volume of specimens without a seal exhibited no changes with time whereas the mean pore radius increased and specific surface area decreased. For specimens subjected to a long term high temperature, total pore volume increased and the pore size distribution shifted to a larger side with the lapse of time. Though this tendency was not confirmed by SEM observation, it may be attributed to a drying of hydration products due to a high temperature $\left(50^{\circ} \mathrm{C}, 60 \% \mathrm{RH}\right)$. The mean pore radius of specimens cured in air was much larger than that cured in water while the total pore volume was not different.

\section{Discussions on the model specimens and conditions in JPDR}

After 26 years of construction, the biological shield concrete in JPDR has been irradiated intermittently by gamma ray and neutron during the 1.3 years of full power operation. Although the dosage cannot be directly linked with the curing conditions of the model specimen, moisture conditions in concrete was assumed to be kept high since the high temperature side of the concrete was covered by a steel liner. Results of the model specimens thus could support the test 
results of hydration and microstructure of biological shield concrete in J PDR.

\section{Conclusions}

This study dealt with hydration behavior and microstructure of biological shield concrete used under a normal operation in JPDR and the model concrete specimens prepared in a variety of curing conditions that were equivalent to the environmental conditions in JPDR. Major findings are as follows.

(1) SEM observations

SEM observation showed that needle-like crystals in concrete exhibited greater development at the reactor core side than at the perimeter, and they had similar shapes to ettringite and C-S-H observed in the model specimens that were cured with No. 2 curing method presuming a location near the reactor core.

(2) X-ray diffraction of hydration products

$\mathrm{X}$-ray diffraction peaks of ettringite were slightly intensive at the reactor core side rather than the perimeter. In model specimens cured by No.2 method presuming a location near the reactor core, intensive peaks associated with ettringite, monosulfate and calcium hydroxide were detected showing agreement with the results of the biological shield concrete in JPDR.

(3) Amount of bound water

Evaporable water content at the reactor core side was $12 \%$ higher than that of the perimeter, and bound water content was $5 \%$ larger at the reactor core side than at the perimeter. Bound water content of model specimens cured with No.2 method, which presumes a location near the reactor core, was average $6.5 \%$ higher than that cured with No.4 method, which presumes a location in the perimeter. This tendency agrees well with the analysis of concrete in JPDR.

(4) Amount of hydration products determined by thermal analysis

Hydration products determined by thermal analysis agreed with the SEM observations when the specimens were subjected to heating at early ages, and showed similar results to the X-ray diffraction analysis when the specimens were subjected to long term heating and with / without a seal.

(5) Pore size distribution and pore volume

Pore size distribution showed larger amount of small pores at the reactor core side than at the perimeter. This tendency agrees well with the model specimens cured with No.2 method with a seal. Total pore volume of specimens at the reactor core side were smaller than that at the perimeter implying a densification.

With above observations and discussions, we may conclude that the hydration and microstructure analysis of the model specimens under an equivalent thermal effects in JPDR, supports the test results that the biological shield concrete undergoes no substantial changes.

\section{Acknowledgments}

We thank those involved in this research for their cooperation; Mr. M. Hatakeyama and Mr. H. Kamata at Tokai Research Laboratory of JAERI, Mr. K. Takahashi and Dr. H. Shiino at Hitachi Cement Corporation. and Mr. K. Tanaka, Mr. T. Konno and Mr. H. Hatano at Kajima Corporation.

\section{References (in Japanese )}

1. Idei, Y., Kamata, H., Akutsu, Y., Onizawa, K., Nakajima, N., and Kakizaki, M. et al., : Mechanical properties of JPDR biological shield concrete, JAERI-M, 90-205, Japan Atomic Energy Research Institute, November, 1990

2. Idei, Y., Sukegawa, T., Nakajima, N., Tataka, M., Konno, T. and Kuruoka, H. : Study of aging for biological shield concrete in JPDR - Part I Overall program and evaluation of environmental factors - , Proceedings of fall meeting of the Atomic Energy Society of Japan 1989, pp. 30, October 1989

3. Kakizaki, M., Idei, Y., Sukegawa, T., Akustu, Y., Hatano, H. and Kurioka H. : Study on environmental and mechanical properties of irradiated concretes, Journal of Structural and Construction Engineering - Transaction of Architectural Institute of Japan - No. 488, pp. 1-10, October 1996

4. Akutsu, Y., Idei, Y., Nakajima, N., Kakizaki, M. and Suzuki, K. : Study of aging for biological shield concrete in JPDR - Part II Test results of the mechanical properties - , Proceedings of fall meeting of the Atomic Energy Society of Japan 1989 , pp. 31, October 1989

5. Kurioka, H., Kakizaki, M., Konno,T., Idei, Y. and Nakajima, N. : Study of aging for biological shield concrete in JPDR - Part III Test results of the chemical properties - , Proceedings of fall meeting of the Atomic Energy Society of Japan 1989 , pp. 397, 0ctober 1990

6. Kurioka, H., Kakizaki, M. , Konno, T., Idei, Y. and Nakajima, N. : Study of aging for biological shield concrete in Nuclear Facility - Part II Test result of the chemical properties - Summaries of Technical Papers of Annual Meeting Architectural Institute of Japan , pp. 179-180, September 1991

7. Suzuki, K., Tanaka, K., Hatano, H., Kamata, H. and Akustu, Y. : Study of aging for biological shield concrete in JPDR Part IVResult of heat exposure test - , Proceedings of fall meeting of the Atomic Energy Society of Japan 1990 , pp. 398, October 1990 


\section{和文要約}

\section{1.はじめに}

今回，研究対象とした原子洷は，日本で初めて発電を行った動 力試験灯 (JPDR) で，長時間，低照射率で照射されたコンクリー 卜椿造物である。そこで，本研究は，放射線を照射された生体遮 蔽コンクリートが中性子および $\gamma$ 線の発熱によってコンクリート の水和特性と微細棈造がどのような影響を受けているかを把握す るためにJPDR ${ }^{31}$ と同様の温度条件下におけるモテルコンクリート 試験体を新たに作製して、それらの挙動について比較検討するこ とによって生体遮蔽コンクリートの物理・化学的变化から発電炬 の寿命を予测する場合の有用な知見を得ることを目的として行っ たものである。

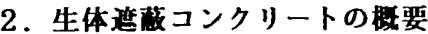

生体遮游コンクリートは $\mathrm{R} \mathrm{C}$ 造で、厚さ $13 \mathrm{~mm}$ の鎆製ライナーが 炬心側内表面に内張りされ、内外表面の中間には中継ぎライナー が眍置され、外表面にはエポキシ系の塗装が施されている。

生体遮蔽コンクリートの概要, 設計条件と調合を、本文 2章と Fig. 1, Table 1に示す。

\section{3. 試験概要}

生体遮蔽コンクリート（実験 1）および放射線照射による温度 の影響を想定したモテル試験体（実験 2）の水和特性と微細構造 に関する試験項目と内容をTable 2 示す。生体遮蔽コンクリート の水和特性之微細構造の挙動は, 放射線照射量の影響をみるため に部材厚さ等の条件を同一として、炬心との位置関係による影㸷 を確認するために平面対称で测定した。試料の採取位置は、Fig. 1 のように放射線照射量が最も多い炬心近房と照射量が少ない炉 心から離れた位置、さらに放射線の照射を極力受けない位置のも のとした。Fig. 3に测定する試料の採取手順を示す。温度の影響 を想定したモデル試験体は, JPDRの建設当時とできるだけ同一の 材料と調合とした。モテル試稀体は，原子炈からの放射線照射に よる熱エネルギーを長期に受けたコンクリートの挙動を再見する ために、Fig. 4に温度の影限を想定した養生条件で行った。モデ ル試験体は、遮敕コンクリートが打込み厚さの大きいコンクリー トであることから，炻心側ライナーに近いところおよびコンクリ 一ト中心部で水分の移動が制限されることを想定して，銅板筒型 枠（厚さ0.3mm，外徍 $15 \mathrm{~mm} ，$ 内高 $30 \mathrm{~mm}$ ）による完全密閉を施すもの をシール有りとし，秇が伝導されて室温に接する部分を想定して シール無しと設定した。想定した温度は、打込み洔の水和反们に 伴う発熱と運転時の放射線の照射に伴う発熱を考虑して、60 した。これらの計算方法は文献 3）の3.3 に，解析結果の要約は， 本文の「4 章」に示した。

\section{4.試䥣方法 \\ （1）生体遮蔽コンクリート \\ 1）走查型電子顕微鏡観察（SEI）}

SEUの観察は，コンクリートの粗粉础試料（乾嬠状態）からモ ルタル部分（3〜5 $\mathrm{mm}^{3} ）$ を採取して真空乾燥した後に，その試 料を割裂した破断面に金を真空蒸着して行った。測定は微小部走 查型電子顕微鏡によって1 試料につき 2 視野とし，倍率は，500， 1000,3000,10000 倍で行った。
2) X 線回折

$\mathrm{X}$ 線回折は $45 \mu \mathrm{m}$ 以下に微粉磁（乾燥状態）したモルタル部分 （約 $1 \mathrm{~g}$ ）をガラス板に均一になるように詰めて, 回折角 $(2 \theta)$ を剆定し（室温：20～ $25^{\circ} \mathrm{C}$ ），Bragg's の条件式に代入して格 子面間隔を求め, JCPDS カードにより同定した5)。 。

3）結合水量及び示差熱分析

結合水量は $45 \mu \mathrm{m}$ 以下に微粉砕したモルタル部分を約 $5 \mathrm{~g}$ 採取し, $40^{\circ} \mathrm{C}$ で24時問乾嬠させた後に電気炬により，105 ${ }^{\circ} \mathrm{C}, 400^{\circ} \mathrm{C}$, $650{ }^{\circ} \mathrm{C}$ 及び $950^{\circ} \mathrm{C}$ で各 1 時間, $650^{\circ} \mathrm{C}$ の娍少率より $105{ }^{\circ} \mathrm{C}$ 減少率

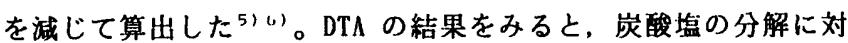
応する600 700 ${ }^{\circ} \mathrm{C}$ 減量はほとんど見られないので, 試料の炭 酸化はほとんどないものと考えて, 結合水量算定上の上限温度を $650{ }^{\circ} \mathrm{C}$ とした。

結合水量の計算

減少率 $(\%)=$ (試耠前の質量一試殹後の質量)

$$
\text { /試験前の質量 } \times 100
$$

結合水 $(\%)=650^{\circ} \mathrm{C}$ 減少率 $-105^{\circ} \mathrm{C}$ 減少率

示差熱分析 (DTA) 曲線は， $45 \mu \mathrm{m}$ 以下の徽粉研試料を約 $10 \mathrm{mg}$ 採取 して, 示差熱分析装置を用いて昇温速度を $10^{\circ} \mathrm{C} / \min$ （室温 : 20 $\sim 25^{\circ} \mathrm{C}$ ) , 温度 $950^{\circ} \mathrm{C}$ まで $a$ アルミナを標準試料として测定した。 示差熱分析の計算

$$
\begin{gathered}
\mathrm{Ca}(\mathrm{OH})_{2} \quad(\%)=440 \sim 500{ }^{\circ} \mathrm{C} \text { の脱水による } \\
\text { 隇量率 } / 0.243{ }^{* 11} \\
\text { *1) }: 0.243=\mathrm{H}_{2} 0 / \mathrm{Ca}(\mathrm{OH})_{2}
\end{gathered}
$$

吸熱ピーク面積比の算定は，3，3.3（1)，3）に示した。

4）細孔径分布（ポロシティ）

細孔量はコンクリートの粗粉砕試料からモルタル部分を約 $30 \mathrm{~g}$

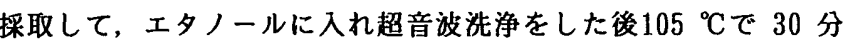
間乾嬠し，水銀胿入式のポロシメー夕を用いて水銀圧力 $0.9 \sim 20$ 00kg/ cố゙で細孔径を6〜9500nmの範囲で測定した。

（2）温度の影響を想定したモテル試験体

水和特性と徽細構造の試铪は, Fig. 3に準じて3.2(2)のコンク リートから骨材を取り除いた微㸮碎試料（乳バチによる）を調製 して, 3.3，(1),1) 4) と同様の方法で SEM観察，X 線回折，結合 水量，熱分析および細孔径分布などについて行った。

5.まとめ

試釦結果およびその考察から、次のような知見を得た。

a. SEM 観察の結果, 針状結晶は炬心側試料の方が外側に比べて 発達の度合いが大きい。それは、モテル試検体のエトリンガイ トとC-S-H の針状結晶と同じであった。

b. 結合水量は，炬心側の方が外側に比べて約 $5 \%$ 大きいが，モ テル試験体では $6.5 \%$ 程度大きくなり，JPDRの分析結果と同じ 傾向を示した。

c 、X線回折による水和生成物は，モテル試験体のときモノサル フェート, $\mathrm{Ca}(\mathrm{OH})_{2}$ のピークが強く検出されており, JPDRの分 析結果と一致していた。

d. 細孔径分布は，炬心側の方が外側より小さい細孔径が多く存 在しており，この頓向はモテル試験体のシール有り（灯心側を 想定）の場合とよく一致していた。

e．モデル試験体の水和特性と微細構造は，生体遮蔽コンクリー トの結果と特に変化を生じていないという試験結果を補足して いるデータの一つであると考えられる。

（1998年 3 月 5 日原稿受理，1998年10月16日採用決定 